\title{
Nucleus of the Tractus Solitarius
} Metastasis: Relationship to Respiratory Arrest?

\author{
Roy H. Rhodes and H. Robert Wightman
}

\begin{abstract}
Background: A 52-year-old woman with metastases in brain and bone had clinical and radiological response to therapy but died about 10 weeks after diagnosis. General autopsy failed to identify a primary neoplasm or an anatomic cause of death. Investigation of sudden respiratory cessation was a consideration when undertaking an anatomic study of the brain. Methods: Review of patient records and careful examination of the brain following autopsy were carried out. Results: The patient had terminal episodes of hypersomnia but episodes of sleep apnea were not observed. She received no respiratory support and no respiratory difficulties were recorded until she was pronounced dead at 7 a.m. Autopsy revealed metastatic adenocarcinoma in a pattern suggestive of a primary pulmonary neoplasm, including multiple cerebral metastases, although no significant pulmonary lesions of any type were found. A 0.2 $\mathrm{cm}$ metastatic adenocarcinoma was found in the nucleus of the tractus solitarius (NTS). No other tumor was present in the brain stem. Conclusions: Unilateral destruction of the NTS in the medulla would have severely disturbed the most critical point of convergence of autonomic and voluntary respiratory control and of cardiocirculatory reflexes in the central autonomic network. It is postulated that this caused respiratory arrest during a state transition from sleeping to waking. Few metastases to the medulla are reported, most are relatively large, and several have caused respiratory symptoms before death. The very small metastasis in our patient could be the direct anatomic cause of death, and as such it is an unusual complication of metastatic disease of which clinicians should be aware. It is speculated that dysfunction of direct NTS connections to the pons or of connections passing close to the metastatic deposit resulted in terminal hypersomnia.
\end{abstract}

RÉSUMÉ: Métastases dans le noyau du faisceau solitaire: y a-t-il un lien avec l'arrêt respiratoire? Introduction: Une femme âgée de 52 ans porteuse de métastases cérébrales et osseuses a eu une réponse clinique et radiologique au traitement mais elle est décédée environ 10 semaines après le diagnostic. Une autopsie n'a pas pu identifier un cancer primaire ou une cause anatomique de décès. À l'examen anatomopathologique du cerveau, on a recherché la cause de l'arrêt respiratoire subit. Méthodes: Il s'agit d'une revue de dossiers de patients et d'examens anatomopathologiques de cerveaux. Résultats: La patiente a eu des épisodes d'hypersomnie en phase terminale mais aucun épisode d'apnée du sommeil n'a été observé. Elle n'a pas reçu d'assistance respiratoire et aucune difficulté respiratoire n'a été notée jusqu'à ce que son décès ne soit constaté à 7 am. Une autopsie a révélé un adénocarcinome métastatique dont l'aspect était suggestif d'une néoplasie pulmonaire primaire, dont de multiples métastases cérébrales, bien qu'on n'a retrouvé aucune lésion pulmonaire significative de quelque type que ce soit. Un adénocarcinome métastatique de $0.2 \mathrm{~cm}$ a été retrouvé dans le noyau du faisceau solitaire (NFS). Il n'y avait aucune autre tumeur dans le tronc cérébral. Conclusions: Une destruction unilatérale du NFS dans le bulbe aurait sévèrement perturbé le point de convergence le plus critique du contrôle respiratoire autonome et volontaire et des réflexes cardiocirculatoires dans le réseau autonome central. Nous postulons qu'il s'agit là de la cause de l'arrêt respiratoire pendant un état de transition entre le sommeil et l'éveil. Peu de métastases bulbaires ont été rapportées, la plupart étant relativement grosses et plusieurs ayant causé des symptômes avant le décès. La petite métastase chez notre patiente pourrait être la cause anatomique directe de son décès et comme tel il s'agit d'une complication inusitée de la maladie métastatique que les cliniciens devraient connaître. Nous émettons l'hypothèse qu'une dysfonction des connections directes entre le NFS et le pont ou des connections passant près du dépôt métastatique a causé l'hypersomnie terminale.

Can. J. Neurol. Sci. 2000; 27: 328-332

Destruction of centres in the medulla in patients developing breathing irregularities or suffering respiratory arrest has been reported for tumors, ${ }^{1-6}$ infarcts, infections, and other types of lesions. ${ }^{7-15}$ Key cardiorespiratory regions affected in the medulla most often include the nucleus of the tractus solitarius (NTS), the nucleus ambiguus, and the ventrolateral reticular formation. ${ }^{3-16}$ We report a patient with radiologically-demonstrated cerebral and osseous metastases who suffered a fatal respiratory arrest and who proved at autopsy to have only one small metastasis in the brain stem.

\section{CASE REPORT}

A 52-year-old previously healthy female smoker had sudden onset of seizures. Radiologic imaging revealed scattered cerebral and osseous lesions presumed to be metastatic carcinoma. No primary lesion was

\footnotetext{
From the Department of Pathology, University of Manitoba, (RHR) and Department of Pathology, Grace General Hospital, (HRW) Winnipeg, MB Canada

ReCeived January 3, 2000. ACCEPTED Infinalform June 20, 2000. Reprint requests to: R.H. Rhodes, Health Sciences Centre, Department of Pathology, MS-459, 820 Sherbrook Street, Winnipeg, MB R3A1R9 Canada
} 
found. Seizures did not recur, but she developed confusion, headache, nausea and vomiting, and eventually weakness, dizziness, unsteady gait, regional extremity numbness, disorientation, memory loss and cognitive impairment. She also had sudden episodes of drowsiness during the day. She had no reported or witnessed respiratory difficulties. A course of whole-brain radiotherapy given in five fractions (2,000 cgy total) and dexamethasone was followed by symptomatic improvement and slight shrinkage of cerebral lesions. The only blood count abnormality was a slightly elevated red cell distribution width (17; high normal, 14.5). Serum $\mathrm{CO}_{2}$ was in the reference range nine days before death. She was ambulatory until a week before she died. Following radiotherapy, only palliative care without respiratory support was provided. No further diagnostic measures were undertaken. Haloperidol was given until her final week. She was restless and agitated, and she continued to be drowsy, sleeping most of the time during the final week. She was maintained only under light sedation with $60 \mathrm{mg}$ of phenobarbital every 12 hours (phenobarbital level was slightly below therapeutic range). Observations were done regularly every 15 minutes for nine days before death. No ataxic breathing was ever noted. Death was observed at 7 a.m. when the patient stopped breathing, about 10 weeks after the episode of seizures. There was no cardiac monitoring except in pronouncing death.

Careful search during the general autopsy revealed no anatomic cause of death. Microscopy revealed a $0.2 \mathrm{~cm}$ deposit of adenocarcinoma in a parabronchial lymph node and another in the right adrenal gland. There were small osseous metastases. Pneumonia was not found in the lungs and no pulmonary neoplasm was identified. External examination of the brain showed only slight gyral flattening. The circle of Willis and the vertebrobasilar arteries had mild arteriosclerosis. Coronal sections of the cerebral hemispheres revealed about a dozen widely scattered $0.2 \mathrm{~cm}$ to $1.5 \mathrm{~cm}$ lesions in the neocortex or at the corticomedullary border. The insula was not involved. The larger two lesions were gray-tan and partly cavitated. The smaller lesions were yellow-gray. Deep cerebral structures, cerebellum, brain stem, and upper cervical spinal cord were grossly normal. Microscopic sections of the cerebral lesions revealed adenocarcinoma with hemorrhage and cholesterol clefts. Some nuclear grooves and optically empty nuclei prompted an immunostain for thyroglobulin. This was negative, ruling out metastasis from the thyroid gland. Estrogen and progesterone receptor immunostaining that might be found in some breast and pelvic

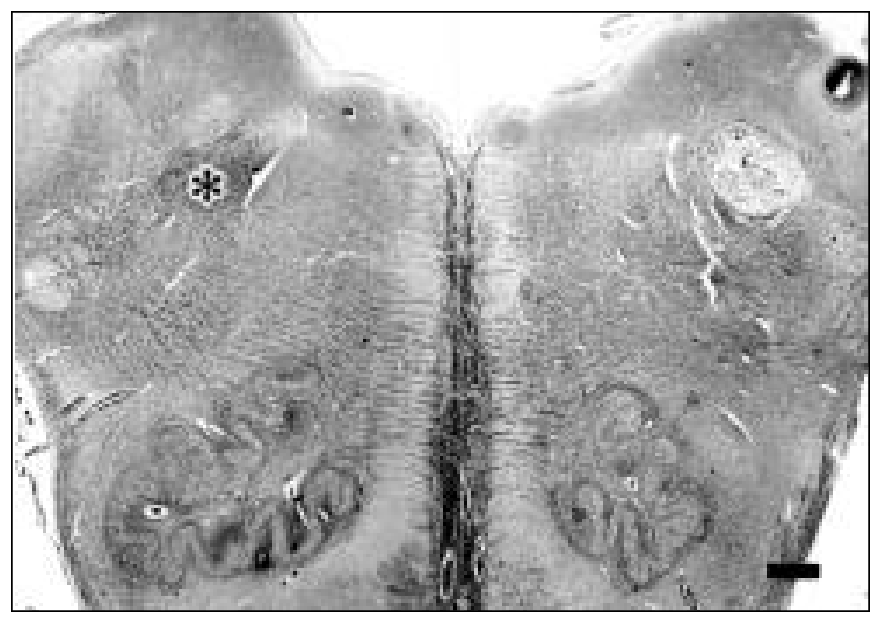

Figure 1A: Bielschowsky silver-impregnated composite view of upper medulla with normal nucleus of the tractus solitarius $(*)$ on the left side and metastatic tumor replacing the nucleus on the right. Bar $=1 \mathrm{~mm}$. tumors was also negative. These metastatic tumors resembled the osseous, adrenal and lymph node metastases. There was a $0.4 \mathrm{~cm}$ metastatic tumor in the inferior vermis of the cerebellum that had not been seen grossly. A $0.20 \times 0.13 \mathrm{~cm}$ metastatic adenocarcinoma was in the right side of the dorsolateral medulla near the level of the pontomedullary junction, and it replaced the NTS at that level (Figure 1). A small rim of pallor adjacent to the metastatic tumor would have included subnuclei of the solitary tract and any other passing axons in this zone. Bielschowsky silver impregnation demonstrated the focal NTS destruction (Figure 1A). Multiple levels of the entire brain stem were examined and no other brain stem metastases were found. No leptomeningeal tumor deposits were found. A small metastatic tumor was present in the superficial aspect of a posterior horn of the upper cervical spinal cord.

\section{DisCUSSION}

Most metastases to the brain stem occur in association with cerebral metastase ${ }^{17,18}$ and they are usually due to pulmonary carcinoma, ${ }^{17-24}$ as is metastatic disease to the brain in general. ${ }^{25-}$ 28 It has long been recognized that pulmonary carcinomas may have very small primary lesions, and in cases with cerebral metastases and no primary tumor identified at autopsy, the possibility of a pulmonary primary is often considered. ${ }^{17,29,30}$ Metastasis to the brain is common in lung cancer patients overall, ${ }^{31,32}$ and pulmonary adenocarcinoma is the single most common neoplasm to metastasize to the brain. ${ }^{25,27,33,34}$ Pulmonary adenocarcinomas also commonly metastasize to parabronchial lymph nodes, liver, adrenals, and bone. ${ }^{25,27}$ Except for a negative finding in the liver, this is the metastatic pattern in our case. Therefore, even without a primary tumor having been identified, the tumors in our case have every appearance of being metastatic from a lung. Pulmonary adenocarcinoma may present first as metastatic disease as in our patient, although this is uncommon. ${ }^{25,27,29,34}$

Patients developing brain metastases from pulmonary adenocarcinoma have a shortened survival, ${ }^{35}$ and this is true from intracranial spread of other malignancies. ${ }^{36-39}$ In general, the malignant process itself is considered as the cause of death

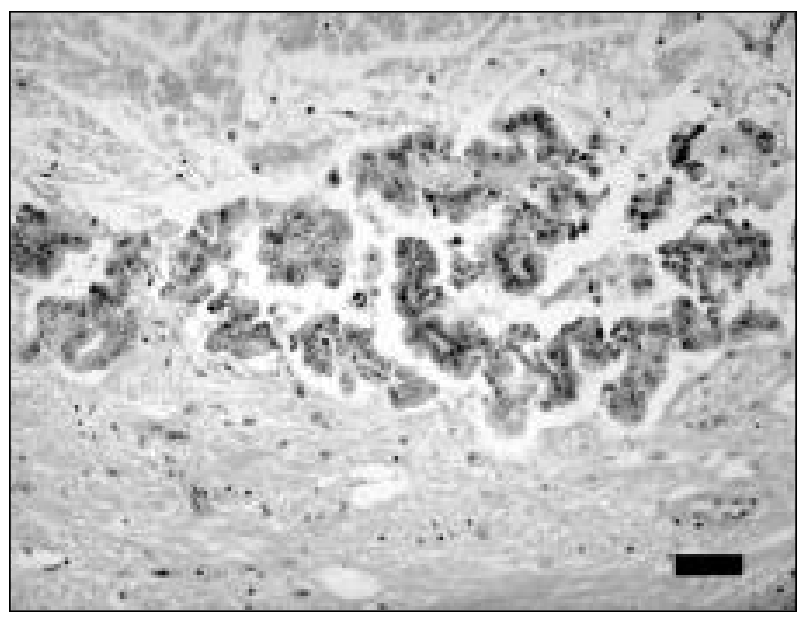

Figure 1B: H\&E-stained section of region of nucleus of the tractus solitarius in right side of upper medulla showing metastatic papillary adenocarcinoma with viable tumor at brain margin and central necrosis. Bar $=200 \mu \mathrm{m}$. 
when metastases are widespread to the brain and other organs, with the presence of coma, organ failure and metabolic abnormalities not recognized in our patient. ${ }^{40}$ Cranial radiation can prolong survival in patients with brain metastases from pulmonary and other adenocarcinomas, and it is more likely to do so when brain is the only significant site of metastatic spread. ${ }^{31,39,41-44}$ The adverse effect of skeletal metastases appears to be significantly less than for brain metastases, even though pain, pathologic fractures and spinal cord compression can provide significant morbidity. ${ }^{37,45-51}$ For metastatic breast carcinoma, $9-14 \%$ of patients with brain metastases die from a central nervous system cause, ${ }^{45,52}$ and in similar studies of various primaries the majority of patients die of extracranial disease. $^{28,53}$ For colorectal carcinoma, survival may not be affected by the presence or extent of metastatic brain disease. ${ }^{54}$ The location of a single brain metastasis from non-small cell pulmonary carcinoma does not affect survival. ${ }^{55}$ However, brain metastases are often multiple and non-small cell lung cancer deaths are more closely related to neurological causes in one study, although specific medullary involvement is not documented. ${ }^{56}$ In our patient, the initial neurologic problems had not worsened after palliative treatment.

Metastatic tumors to the medulla oblongata are unusual, and most of them involve a relatively large proportion of medullary tissue at least on one side..$^{2,6,17-19,21-23}$ Dorsolateral, dorsomedial and ventrolateral medullary regions are often destroyed in cases

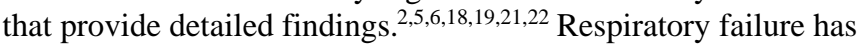
only been reported in tumors metastatic to the medulla on a few occasions. ${ }^{1,2,6}$ A question arises concerning the role of a small, unilateral medullary lesion in causing respiratory arrest.

Unilateral destruction of the NTS appears to be one process in developing respiratory symptoms involving automatic responses, even though damage to other central autonomic centres may be required to cause autonomic respiratory failure. ${ }^{10,13}$ Some NTS axons may cross to the opposite side, which would explain a bilateral effect on respiratory drive from a unilateral lesion. ${ }^{10}$ Voluntary respiratory signals descend in the corticospinal tracts, ${ }^{57}$ yet the NTS and other respiratory nuclei appear to have a role in the integration of automatic and voluntary respiratory efforts. ${ }^{10}$ The NTS is the nuclear and connecting structure that drives, monitors and modifies cardiac, circulatory and respiratory function. The NTS has critical connections to centres in the ventrolateral medulla driving cardiac signals and it is the central control point for cardiovascular and respiratory motor signals as they are passed on to other components of the central autonomic network. It receives input from cardiovascular receptors and it integrates autonomic afferent information with its own output and with integrated information from the rest of the central autonomic network to influence respiration and circulation. ${ }^{11,58,59}$ The interconnected dorsal and ventral medullary nuclear groups are primary sites that integrate and drive automatic respiration. The NTS itself is an important connection between dorsal and ventral areas that contribute bilateral inputs into the NTS, so that central medullary lesions will disrupt efferent second and afferent third order neurons transmitting signals of the respiratory central pattern generators. ${ }^{59,60}$ This prevents the final message to spinal motoneurons and prevents automatic initiation of respiratory muscle activity. ${ }^{61,62}$ Precise localization of respiratory drive and relative functional strength at specific levels of connections varies between species $^{59}$ and these networks have yet to be adequately explored in man. ${ }^{14}$

A unilateral NTS lesion is not clearly demonstrated to have caused outright respiratory arrest, and respiratory failure is unusual even with documented medullary metastases. However, the lesion found in the central autonomic region in our patient is restricted to the NTS area. This includes a thin zone of immediately surrounding pallor that indicates edema which would be expected to be disruptive to passing axons of the reticular formation. Since the NTS is a major integration centre with known involvement in cases of respiratory difficulty, ${ }^{3-16}$ and since effects of the rim of apparent edema around the metastatic deposit would have only enhanced the dysfunction of adjacent central autonomic centres, the unilateral NTS-centred lesion is probably ultimately responsible for respiratory dysregulation leading to respiratory arrest.

Primary sleep apnea or sleep disordered breathing dissociated from waking respiratory problems is difficult to assign in this case, although it can occur with unilateral medullary lesions. ${ }^{10,13,14}$ Such an event would be described as Ondine's curse. ${ }^{63}$ Our case may differ by demonstrating a dysregulation of the central autonomic network from the small, unilateral metastatic tumor in the critical NTS circulatory and respiratory initiation and relay centre, rather than by causing a block of descending respiratory drive. It is thought that in the immature nervous system the regulation of breathing is at risk during transition from sleep to the waking state. ${ }^{64}$ Perhaps in this patient's mature nervous system, with focal destruction of the critical NTS region, a similar dysregulation occurred at this "state" transition. This may have lead to sudden autonomic, as well as voluntary, dysfunction with failure of effective transition from one state to the other, resulting in respiratory or cardiorespiratory arrest. Given the scattered cerebral lesions, it is also possible that an effect on voluntary breathing may have occurred, and this might also be a factor in failed state transition. The possibility that a seizure was involved in respiratory arrest cannot be excluded, ${ }^{65}$ although there was no documented seizure activity after the initial clinical episode. In fact, the cerebral metastases were reduced in size after radiotherapy and symptomatic improvement was noted.

There is no clinical or autopsy evidence of upper respiratory or peripheral pulmonary dysfunction in our patient, but hypersomnia was observed. Hypersomnia was not paired with apnea such as can occur in chronic pulmonary disease, and waking hypoventilation is not a feature in this case. ${ }^{66}$ It is possible that the sudden episodes of drowsiness and terminal somnolence may have been contributed to by the solitary metastasis in the NTS zone since sedation remained at a low level terminally. The NTS has interconnections to pontine centres for the sleep-waking cycle ${ }^{67-69}$ and the rim of pallor around the metastatic deposit involves a central region of control in the brain stem reticular activating system. ${ }^{70}$ However, another small brain stem lesion in the reticular activating system that could have been missed may have altered the sleep-waking cycle, ${ }^{71-73}$ or a small unseen thalamic metastasis could have played a role in hypersomnia. ${ }^{74}$

Sudden respiratory irregularities, and indeed sudden death, are potential problems faced by emergency medicine personnel 
and by forensic specialists. Lesion of the central autonomic network by a variety of diseases is a well-known cause of respiratory abnormalities, ${ }^{11}$ including rare cases of respiratory failure from a tumor metastatic to the medulla ${ }^{2,6}$ or encroaching on the medulla. ${ }^{1}$ To this can be added metastatic carcinoma isolated to the NTS zone in the rostral medulla with a presentation of respiratory arrest as the only manifestation of respiratory failure. Terminal hypersomnia can be caused by a lesion of the brain stem central autonomic network, but whether it can be associated with a small disruption of the interrelated and neighboring NTS remains to be proved.

\section{ACKNOWLEDGEMENTS}

We thank Mrs. Sharon Allen and Mrs. Susan Janeczko for excellent technical assistance. Mr. Gary Burgess assisted with photomicrography.

\section{REFERENCES}

1. McFarland HR, Truscott BL. A brain stem lesion of unusual etiology: a case report. Neurology 1961; 11: 597-600.

2. Delaney P, Martinez J. Solitary metastasis to the medulla oblongata. South Med J 1983; 76: 1324-1325.

3. Sanford RA, Smith RA. Hemangioblastoma of the cervicomedullary junction. Report of three cases. J Neurosurg 1986; 64: 317-321.

4. Osanai S, Iida Y, Nomura T, et al. A case of unilateral brain stem tumor and impaired ventilatory response (Jpn). Nihon Kyobu Shikkan Gakkai Zasshi 1994; 32: 990-995.

5. Wolfe GI, Raps EC, Galetta SL, et al. Systemic non-Hodgkin's lymphoma manifesting as neurogenic respiratory failure. Neurology 1995; 45: 589-590.

6. Corne S, Webster K, McGinn G, St-John W, Younes M. Medullary metastasis causing impairment of respiratory pressure output with intact respiratory rhythm. Am J Respir Crit Care Med 1999; 159: 315-320.

7. Levin BE, Margolis G. Acute failure of automatic respirations secondary to a unilateral brain stem infarct. Ann Neurol 1977; 1: 583-586.

8. Beal MF, Richardson EP Jr, Brandstetter R, Hedley-Whyte ET, Hochberg FH. Localized brain stem ischemic damage and Ondine's curse after near-drowning. Neurology 1983; 33: 717721.

9. Hashimoto Y, Watanabe S, Tanaka F, Uyama E, Araki S. A case of medullary infarction presented lateral medullary syndrome and respiratory arrest after ataxic respiration (Jpn). Rinsho Shinkeigaku 1989; 29: 1017-1022.

10. Bogousslavsky J, Khurana R, Deruaz JP, et al. Respiratory failure and unilateral caudal brain stem infarction. Ann Neurol 1990; 28 : 668-673.

11. Benarroch EE. The central autonomic network: functional organization, dysfunction, and perspective. Mayo Clin Proc 1993; 68: 988-1001.

12. Deguchi K, Takeuchi H, Yamada A, Fujita M, Tsukaguchi M. A case of multiple sclerosis with intractable hiccup and acute respiratory arrest (Jpn). Rinsho Shinkeigaku 1994; 34: 854-856.

13. Vingerhoets F, Bogousslavsky J. Respiratory dysfunction in stroke. Clin Chest Med 1994; 15: 729-737.

14. Auer RN, Rowlands CG, Perry SF, Remmers JE. Multiple sclerosis with medullary plaques and fatal sleep apnea (Ondine's curse). Clin Neuropathol 1996; 15: 101-105.

15. Giangaspero F, Schiavina M, Sturani C, Mondini S, Cirignotta F. Failure of automatic control of ventilation (Ondine's curse) associated with viral encephalitis of the brain stem: a clinicopathologic study of one case. Clin Neuropathol 1988; 7 : 234-237.

16. Martin E, Burger R, Wiestler OD, et al. Brain stem lesion revealed by MRI in a case of Leigh's disease with respiratory failure. Pediatr Radiol 1990; 20: 349-350.
17. Hare CC, Schwarz GA. Intracerebral carcinomatous metastases. Arch Intern Med 1939; 64: 542-565.

18. Ho K-L. Uncommon causes of the lateral medullary syndrome. Report of a case of metastatic carcinoma. Arch Neurol 1980; 37: 669-670.

19. Davison C, Spiegel LA. The syndrome of the posterior inferior cerebellar artery resulting from a metastatic neoplasm. J Neuropathol Exp Neurol 1945; 4: 172-177.

20. Masucci EF. Posterior fossa metastases simulating primary tumors. Acta Neurol Scand 1966; 42: 589-603.

21. Case Records of the Massachusetts General Hospital (Case 331971). N Engl J Med 1971; 285: 449-456.

22. Ogawa M, Yamanouchi H, Togi H, Tomonaga M, Kameyama M. Autopsy case of Wallenberg's syndrome caused by metastasis of lung neoplasm to the medulla oblongata (Jpn). Rinsho Shinkeigaku 1977; 17: 25-30.

23. Moffie D, Stefanko SZ. Intramedullary metastasis. Clin Neurol Neurosurg 1980; 82-83: 199-202.

24. Simpson RK Jr, Sirbasku DM, Baskin DS. Solitary brain stem metastasis: comparisons of X-ray computed tomography and magnetic resonance imaging to pathology. J Neurooncol 1987; 5: 57-63.

25. Carter D, Eggleston JC. Tumors of the Lower Respiratory Tract. Atlas of Tumor Pathology. 2nd series. Fascicle 17. Washington, DC: Armed Forces Institute of Pathology, 1980.

26. Nussbaum ES, Djalilian HR, Cho KH, Hall WA. Brain metastases. Histology, multiplicity, surgery, and survival. Cancer 1996; 78 : 1781-1788.

27. Rosai J. Lung and pleura. In: Ackerman's Surgical Pathology. 8th ed. Vol. 1. St. Louis: Mosby-Year Book, Inc., 1996: 338-434.

28. Nguyen LN, Maor MH, Oswald MJ. Brain metastases as the only manifestation of an undetected primary tumor. Cancer 1998; 83: 2181-2184.

29. Latief KH, White CS, Protopapas Z, Attar S, Krasna MJ. Search for a primary lung neoplasm in patients with brain metastasis: is the chest radiograph sufficient? AJR Am J Roentgenol 1997; 168: 1339-1344.

30. McLendon RE, Enterline DS. Tumors of specialized tissues of central neuroepithelial origin. In: Bigner DD, McLendon RE, Bruner JM, eds. Russell and Rubinstein's Pathology of Tumors of the Nervous System. 6th Ed. Vol. 2. New York: Oxford University Press, 1998: 48.

31. Komaki R, Cox JD, Stark R. Frequency of brain metastasis in adenocarcinoma and large cell carcinoma of the lung: correlation with survival. Int J Radiat Oncol Biol Phys 1983; 9: 1467-1470.

32. Sen M, Demiral AS, Cetingoz R, et al. Prognostic factors in lung cancer with brain metastasis. Radiother Oncol 1998; 46: 33-38.

33. Tarver RD, Richmond BD, Klatte EC. Cerebral metastases from lung carcinoma: neurological and CT correlation. Work in progress. Radiology 1984; 153: 689-692.

34. Reyes CV, Thompson KS, Jensen JD. Cytopathologic evaluation of lung carcinomas presenting as brain metastasis. Diagn Cytopathol 1999; 20: 325-327.

35. Tang SG, Lin FJ, Leung WM. Impact of prophylactic cranial irradiation in adenocarcinoma of the lung. J Formos Med Assoc 1993; 92: 413-419.

36. Cormio G, Lissoni A, Losa G, et al. Brain metastases from endometrial carcinoma. Gynecol Oncol 1996; 61: 40-43.

37. Farnell GF, Buckner JC, Cascino TL, et al. Brain metastases from colorectal carcinoma. The long-term survivors. Cancer 1996; 78: 711-716.

38. Culine S, Bekradda M, Kramar A, et al. Prognostic factors for survival in patients with brain metastases from renal cell carcinoma. Cancer 1998; 83: 2548-2553.

39. Sundström JT, Minn H, Lertola KK, Nordman E. Prognosis of patients treated for intracranial metastases with whole-brain irradiation. Ann Med 1998; 30: 296-299.

40. Cho SY, Choi HY. Causes of death and metastatic patterns in patients with mammary cancer. Ten-year autopsy study. Am J Clin Pathol 1980; 73: 232-234.

41. Robin E, Bitran JD, Golomb HM, et al. Prognostic factors in patients with non-small cell bronchogenic carcinoma and brain 
metastases. Cancer 1982; 49: 1916-1919.

42. Decker DA, Decker VL, Herskovic A, Cummings GD. Brain metastases in patients with renal cell carcinoma: prognosis and treatment. J Clin Oncol 1984; 2: 169-173.

43. Berk L. An overview of radiotherapy trials for the treatment of brain metastases. Oncology (Huntingt) 1995; 9: 1205-1212.

44. Lagerwaard FJ, Levendag PC, Nowak PJ, et al. Identification of prognostic factors in patients with brain metastases: a review of 1292 patients. Int J Radiat Oncol Biol Phys 1999; 43: 795-803.

45. Hagemeister FB Jr, Buzdar AU, Luna MA, Blumenschein GR. Causes of death in breast cancer: a clinicopathologic study. Cancer 1980; 46: 162-167.

46. Scheid V, Buzdar AU, Smith TL, Hortobagyi GN. Clinical course of breast cancer patients with osseous metastasis treated with combination chemotherapy. Cancer 1986; 58: 2589-2593.

47. Sherry MM, Greco FA, Johnson DH, Hainsworth JD. Breast cancer with skeletal metastases at initial diagnosis. Distinctive clinical characteristics and favorable prognosis. Cancer 1986; 58:178182.

48. Coleman RE, Rubens RD. The clincal course of bone metastases from breast cancer. Br J Cancer 1987; 55: 61-66.

49. Scher HI, Yagoda A. Bone metastases: pathogenesis, treatment, and rationale for use of resorption inhibitors. Am J Med 1987; 82(2A): 6-28.

50. Patanaphan V, Salazar OM, Risco R. Breast cancer: metastatic patterns and their prognosis. South Med J 1988; 81: 1109-1112.

51. Kanthan R, Loewy J, Kanthan SC. Skeletal metastases in colorectal carcinomas: a Saskatchewan profile. Dis Colon Rectum 1999; 42: 1592-1597.

52. Tsukada Y, Fouad A, Pickren JW, Lane WW. Central nervous system metastasis from breast carcinoma. Autopsy study. Cancer 1983; 52: 2349-2354.

53. Hoskin PJ, Crow J, Ford HT. The influence of extent and local management on the outcome of radiotherapy for brain metastases. Int J Radiat Oncol Biol Phys 1990; 19: 111-115.

54. Alden TD, Gianino JW, Saclarides TJ. Brain metastases from colorectal cancer. Dis Colon Rectum 1996; 39: 541-545.

55. Saitoh Y, Fujisawa T, Shiba M, et al. Prognostic factors in surgical treatment of solitary brain metastasis after resection of nonsmall-cell lung cancer. Lung Cancer 1999; 24: 99-106.

56. Wroñski M, Arbit E, Burt M, Galicich JH. Survival after surgical treatment of brain metastases from lung cancer: a follow-up study of 231 patients treated between 1976 and 1991. J Neurosurg 1995; 83: 605-616.

57. Plum F. The neurological integration of behavioral and metabolic control of breathing. In: Dornhorst AC, ed. Breathing. London: J \& A Churchill, Ltd., 1970.

58. Reis DJ. The brain and hypertension: reflections on 35 years of inquiry into the neurobiology of the circulation. Circulation 1984; 70 (Suppl 3): III31-III45.

59. Dobbins EG, Feldman JL. Brain stem network controlling descending drive to phrenic motoneurons in rat. J Comp Neurol 1994; 347: 64-86.

60. Smith JC, Morrison DE, Ellenberger HH, Otto MR, Feldman JL. Brain stem projections to the major respiratory neuron populations in the medulla of the cat. J Comp Neurol 1989; 281: 69-96.

61. Nathan PW. The descending respiratory pathway in man. J Neurol Neurosurg Psychiatry 1963; 26:487-499.

62. Tranmer BI, Tucker WS, Bilbao JM. Sleep apnea following percutaneous cervical cordotomy. Can J Neurol Sci 1987; 14: 262-267.

63. Severinghaus JW, Mitchell RA. Ondine's curse - failure of respiratory center automaticity while awake. Abstract. Clin Res 1962; 10: 122.

64. Harper RM. State-dependent electrophysiological changes in central nervous system activity. In: Haddad GC and Farber JP, eds. Developmental Neurobiology of Breathing. New York: Marcel Decker, 1991: 521-549.

65. Nelson DA, Ray CD. Respiratory arrest from seizure discharges in limbic system. Report of cases. Arch Neurol 1968; 19: 199-207.

66. Glaser GH, Pincus JH. Neurologic complications of internal disease. In: Baker AB and Baker LH, eds. Clinical Neurology. Vol. 4. Chapter 58. Philadelphia: Harper \& Row, 1983.

67. Eguchi K, Satoh T. Convergence of sleep-wakefulness subsystems onto single neurons in the region of cat's solitary tract nucleus. Arch Ital Biol 1980; 118: 331-345.

68. Lai YY, Siegel JM. Medullary regions mediating atonia. J Neurosci 1988; 8: 4790-4796.

69. Reese NB, Garcia-Rill E, Skinner RD. The pedunculopontine nucleus - auditory input, arousal and pathophysiology. Prog Neurobiol 1995; 42: 105-133.

70. Rye DB, Lee HJ, Saper CB, Wainer BH. Medullary and spinal efferents of the pedunculopontine tegmental nucleus and adjacent mesopontine tegmentum in the rat. J Comp Neurol 1988; 269: 315-341.

71. Tamura K, Karacan I, Williams RL, Meyer JS. Disturbances of the sleep-waking cycle in patients with vascular brain stem lesions. Clin Electroencephalogr 1983; 14: 35-46.

72. Siegel JM. Mechanisms of sleep control. J Clin Neurophysiol 1990; 7: 49-65.

73. Ganji SS, Ferriss GS, Rao J, Furlow J. Hypersomnia associated with a focal pontine lesion. Clin Electroencephalogr 1996; 27: 52-56.

74. Bassetti C, Mathis J, Gugger M, Lövblad KO, Hess CW. Hypersomnia following paramedian thalamic stroke: a report of 12 patients. Ann Neurol 1996; 39: 471-480. 